\title{
Ostracoda Species from Upper Triassic of Baluti Formation (Amadiya Section) in Northern Iraq
}

\author{
Sanad A. Al-Khashab \\ Department of Geology \\ College of Science \\ University of Mosul
}

\author{
Jawaher M. Al-Halawachi \\ Department of Geology \\ College of Science \\ University of Mosul
}

(Received 21/1/2018 ， Accepted 10/7/2018)

\begin{abstract}
Five ostracode species have been described from Baluti Formation (Upper Triassic) of North Iraq, these are Fabanella A, Hungarella moorei (Jones)-Anderson, 1964, Ogmoconcha cf. blakei (Sohn, 1968), Ogmoconcha bristolensis (Anderson, 1964), Cytherella acuta Urlichs, 1972.

Keywords: Ostracode, Baluti Formation, Upper Triassic, North Iraq.

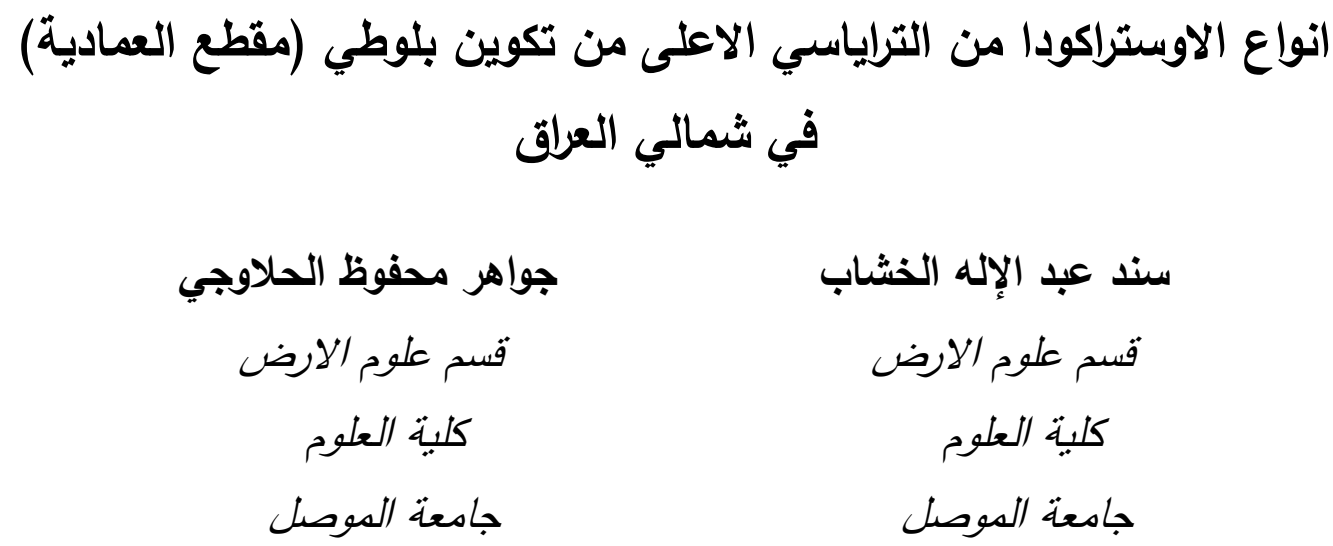

تم وصف خمسة أنواع من الأوستراكودا من تكوين بلوطي (التراياسي الاعلى)، وهذه الأنواع هي:

Fabanella A, Hungarella moorei (Jones)-Anderson, 1964 , Ogmoconcha cf. blakei (Sohn,1968), Ogmoconcha bristolensis (Anderson, 1964), Cytherella acuta Urlichs, 1972.
\end{abstract}

$$
\text { الكلمات الدالة: اوستراكودا، تكوين بلوطي، التراياسي الاعلى، شمالي العراق. }
$$

\section{LOCATION}

This study investigated Ostracodes from outcrop sections in core of Gara anticline near Sarki Village situated about $(11 \mathrm{~km})$ Southeastern Amadiya City, Dohuk province, Northern Iraq (latitude $36^{\circ} 59^{\prime} 30$ "north and longitude $43^{\circ}$ 32 '20" east) (Figs. 1,2). 


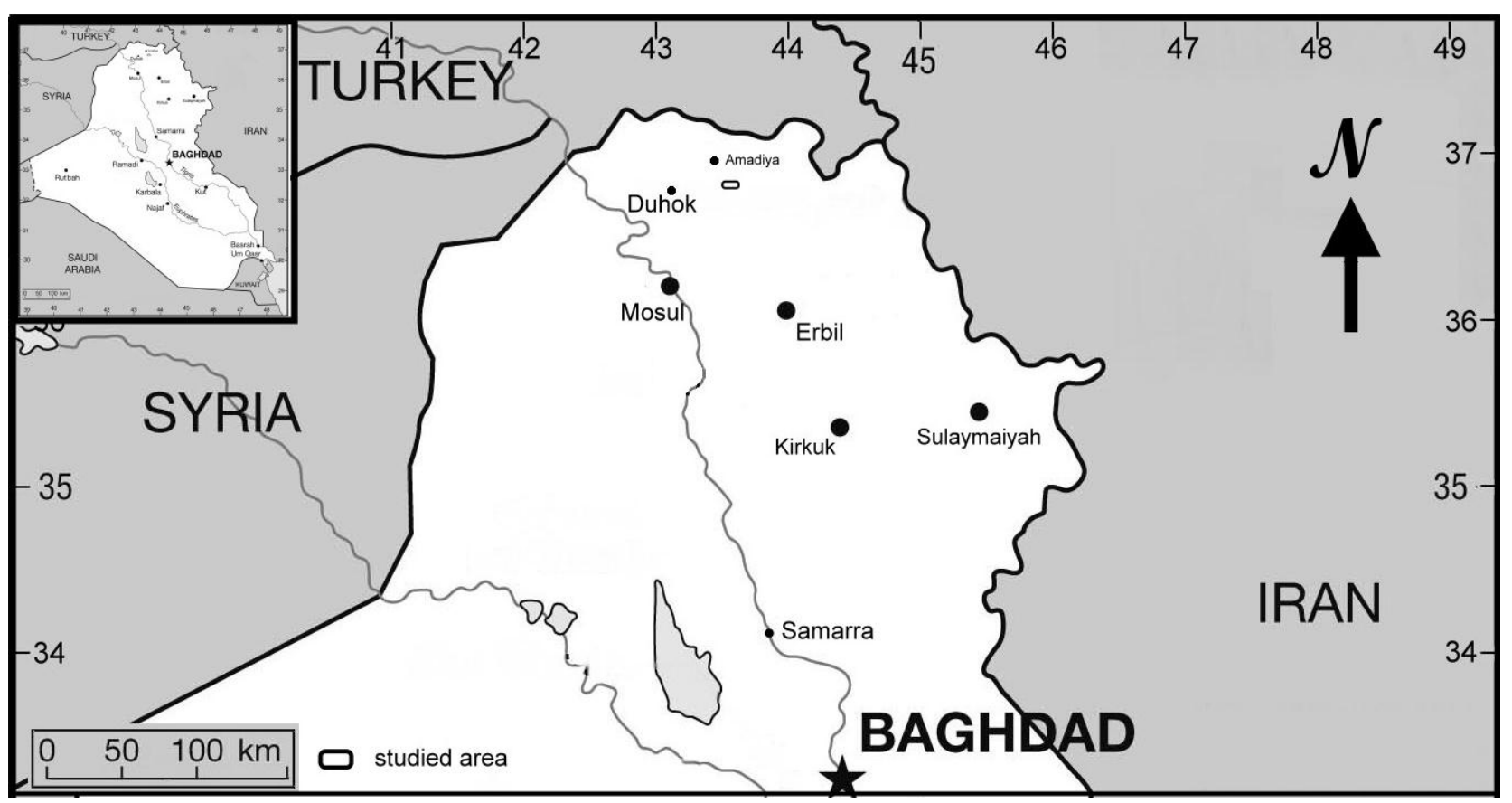

Fig. 1: Northern Iraq map showing the location of the studied area.

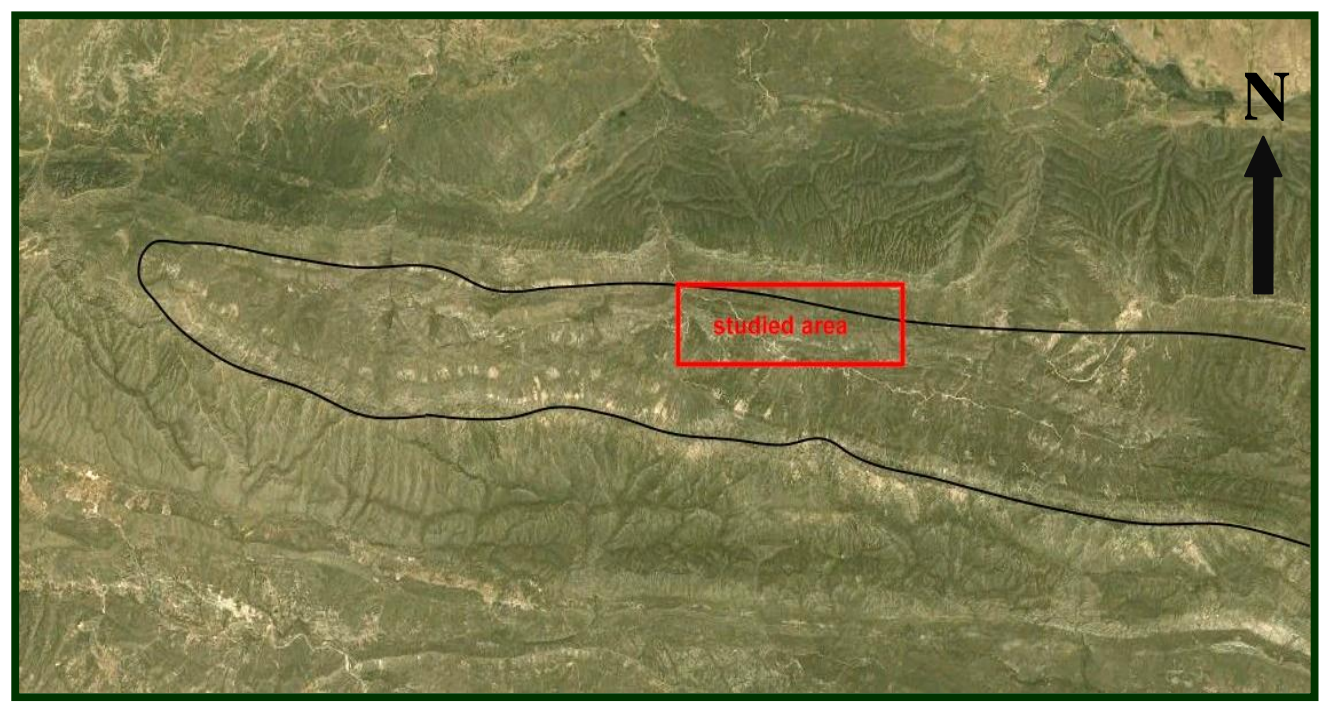

Fig. 2: Satellite image showing the location of the studied section, Gara anticline core.

\section{INTRODUCTION}

Twenty-four samples were collected from the Baluti Formation in the studied section, which is identical to the lithology of the Balambo - Tanjero type section in the High Folded Zone (Bolton, 1958 in Buday, 1980), (Fig. 3). 


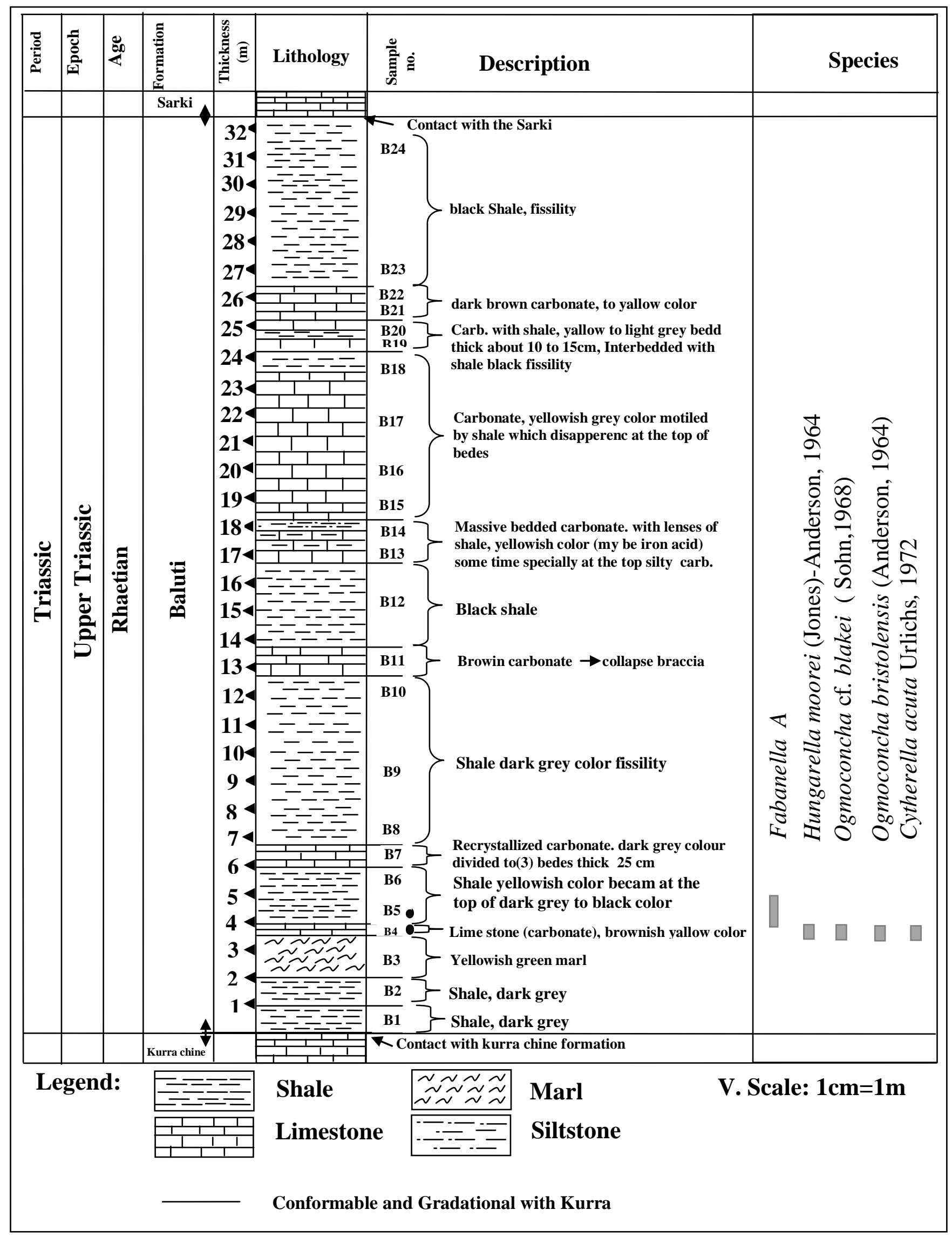

Fig. 3: Lithological section of Baluti Formation, northern Iraq. 
The formation of the studied location is about (32.4 m) thick. Lithologically, the lower part consists of shale, dark grey, yellowish green marl, limestone, brownish yellow color, shale yellowish color became at the top dark grey to black color (fissility), recrystallized carbonate, dark grey color divided into (3) beds with $25 \mathrm{~cm}$ thick, brown carbonate collapse breccias, black shale. Upper part consists massive bedded carbonate with lenses of shale, yellowish color some time especially at the top silty carbonate; carbonate yellowish grey color mottled by shale which disappearance at the top of carbonate beds, with shale, yellow to light grey bed with a thick of 10 to $15 \mathrm{~cm}$. It is interbeded with shale black fissility, dark brown carbonate, to yellow color recrystallized lime. Both lower and upper boundaries of the formation are conformable and gradational (Bellen et al., 1959) except in well Tharthar-1. The conformable nature of the upper contact of the formation of some parts of Iraq (Ga'ara area, western Iraq) seems to be uncertain, due to the ascertained break between Triassic and Liassic, and the widespread and well known break in Triassic and Liassic in Saudi Arabia, southwestern Iran ... etc. (Buday, 1980).

The present work is part of M.Sc. thesis investigating ostracode microfossil from Baluti Formation (Upper Triassic) from Amadiya section, at Geology Dept., Mosul University. All the Figured specimens are deposited at Mosul university with a prefix (MUTBO) which is come from (MU =Mosul University, $\mathrm{T}=$ Triassic, $\mathrm{B}=$ Baluti Formation and $\mathrm{O}=$ Ostracoda $)$.

\section{SYSTEMATIC DESCRIPTION}

The classification of ( Morkhovan, 1963) and (Moore and Pitrat, 1961) was used for the systematic description.

Phylum CRUSTACEA Pennant 1777

Class Ostracoda Laterille 1806

Order Podocopida Muller 1894

Suborder Podocopina Sars 1866

Family Cytherideidae Sars, 1925

Genus Fabanella martin 1961

Type species: Fabanella prima martin 1961

\section{Fabanella A}

(Pl.1, Fig.1)

Material: one carapace.

Occurrence: Baluti Formation, Gara anticline, sample No.B5.

Dimensions (um): Length: 600, Height: 300, L/H: 2, Carapace (LV) MUTBO1:11.

Description: Carapace elongated (sub-rectangular) in outline, dorsal and ventral margin concave, but the ventral margin less than concavity from dorsal margin, surface fine reticulation, anterior broadly rounded, posterior margin acute, maximum height at the cardinal angle, maximum length at the mid height.

Remarks: The Iraqi species similar to Fabanella boloniensis (Jones) which recorded by the Anderson (1964), But differs in dorsal and ventral margins of Iraqi 
type concavity more than the British type. The present species left under open name due to the lack of materials.

Suborder Metacopina Sylvester-Bradley 1961

SuperFamily Healdiacea Harlton 1933

Family Healiidea Harton 1933

Genus Hungarella Mehes 1911

Type species: Bairdia? Problematica Mehes, 1911, p. 21, pl. 2, Fig. 14 - 18.

Hungarella moorei (Jones)-Anderson, 1964

(Pl.1, Fig.2, 3)

1894 Cytheridea moorei, Jones, p. 165, pl. 9, Figs. 7 - 8. 1951'Ostracode 799'

Wicher, pl. 1, Fig. U.

1964 Hungarella moorei (Jones)-Anderson, p. 149, pl. 5, Fig. 94 - 95.

Material: Two carapace.

Occurrence: Baluti Formation, Gara anticline, sample No. B4

Dimensions (um): Length: 500, Height: 400, L/H: 1. 25, Carapace (LV) MUTBO1:3.

Length: 450, Height: 300, L/H: 1. 25, Carapace (LV) MUTBO1:4.

Description: carapace ovoid, small size with fine pitted surface, anterior margin narrow rounded, posterior margin broadly and evenly rounded, dorsal margin convex, ventral margin slightly convex .

Remarks: The Iraqi species similar to the Hungarella moorei (Jones), p. 149, pl. 5, Fig. 94 - 95. From Rhaetic Ostracoda from Britain, but differ from more convexity of dorsal margin.

Genus:Ogmoconcha Triebel, 1941

Type species: Ogmoconcha contractual Triebel, 1941, p. 377, pl. 14, Figs, 156-160.

Ogmoconcha cf. blakei (Sohn, 1968)

(Pl.1, Fig.4,5)

1992 Ogmoconcha cf. blakei (Sohn,1968) - Depeche and Crasquin, p. 461,

Material: Tow carapace.

$$
\text { pl.4, Fig. } 2
$$

Occurrence: Baluti Formation, Gara anticline, sample No.B4.

Dimensions (um): Length: 600, Height: 450, L/H: 1.5, Carapace (LV) MUTBO1:5.

Length: 650, Height: 450, L/H: 1.44, Carapace (DV) MUTBO1:6.

Description: Carapace semi-oval, dorsal and ventral margins convex, smooth surface, anterior margin broadly, posterior margin narrowly rounded, maximum length at the mid carapace, maximum height at the mid length.

Remarks: The Iraqi species similar to Ogmoconcha cf. blakei (Sohn, 1968), p.461, pl.4, Fig.2. but differs from having strongly convex dorsal margin. 
Ogmoconcha bristolensis (Anderson, 1964)

( (pl. 1, Fig. 6,7$)$

1992 Ogmoconcha bristolensis (Anderson, 1964)-Depeche and Crasquin, p.461,

Material: One carapace.

$$
\text { pl.4, Fig. } 3 .
$$

Occurrence: Baluti Formation, Gara anticline, sample no.B4.

Dimensions (um): Length: 600, Height: 400, L/H: 1.5, Carapace (LV) MUTBO1:9.

Description: Carapace semi-oval, dorsal and ventral margins slightly convex, smooth surface, anterior margin broadly rounded, posterior margin narrowly rounded.

Remarks: The Iraqi specimens completely identical with the Ogmoconcha bristolensis (Anderson, 1964), recorded by the Depeche and Crasquin of Australian.

Suborder Platycopina Sars 1866

Family Cytherellidae Sars 1866

Genus Cytherella Jones 1849

Type species: Cytherella Ovata Romer, 1840,P.104, PL.16, Fig.21.

Cytherella acuta Urlichs, 1972

(pl.1, Fig.8, 9)

1972 Cytherella acuta Urlichs Depeche and Crasquin, p. 460, pl. 3, Fig. 8.

Material: one carapace.

Occurrence: Baluti Formation, Gara anticline, sample No.B4.

Dimensions (um): Length: 700, Height: 400, L/H: 1.75, Carapace (LV) MUTBO1:1.

Length: 700, Height: 400, L/H: 1.75, Carapace (RV) MUTBO1:2.

Description: Carapace small size, shape elongated (sub-rectangular), surface smooth to finely pit, maximum length along central line of the carapace. Dorsal and ventral margin nearly parallel. Anterior margin broadly and evenly rounded, posterior margin rounded, right valve larger than the left valve. Overlap seen along the carapace margins.

Remarks: The Iraqi species is similar to Cytherella acuta Urlichs, p. 460, pl. 3, Fig. 8. from Australian, but differ in ornamentation.

\section{REFERENCES}

Anderson, F. W., 1964. Rhaetic Ostracoda. Bull. Geol. Surv. G. B, Vol. 21, pp. 133 - 176.

Bellen, R.C.,Van, Dunnington, H.V., Wetzel, R, Morton, D, 1959: Lexique Stratigraphique International Asie, Iraq. Intern. Geol. Conger. Comm. Stratigr.3, Fasc.10a. 333p. 
Bolton,C.M., 1958: The geology of the Ranya area. Manuscript report No.271, GEOSURB,Baghdad.

Buday, T., 1980. The Regional Geology of Iraq. Vol. 1: Stratigraphy and Paleogeography. Publications of GEOSURV., Baghdad, 445 p.

Depeche, F. and Crasquin, S., 1992. Triassic Marine Ostracodes of the Australian Margin (Holes 759B, 760B, 761C,764A, AND 764B).Proceedings of the Ocean Drilling Program, Scientific Results, 122: pp. 453 - 462.

Jones, T, R., 1894. Rhaetic and some Liassic Ostracoda of Britain. Quart.J. Geol. Soc, 50: pp. 69 - 156.

Mehes, G.,1911. Uber Triasostracoden aus dem Bakony.- Result. wiss. Erforsch. Balatonsee. 1, Anh. Palaont.,S. pp. 1 - 38, 6 Abb., 4 Taf.

Morkhoven, F.P.C. M. Van., 1963. Post - Paleozoic Ostracoda, Their Morphology, Taxonomy and Economic Use, Part 2. Elsevieer Published Company,: pp. 1 - 478.

Moore, R.C. and Pitrat, G. W., 1961. Treatise on invertebrate. Paleontology, Part Q Arthropoda 3 Crustacea Ostracoda. Geol. Soc. Of America and University of Kansas press, Lawrance Kansas, 442 p.

Sars, G, O., 1866. Oversigt at Norges marine Ostracoder. Norske Vidensk.- Akad. Forhandl. 1865., pp. 1 - 130.

Sohn, I, G., 1968. Triassic Ostracodes from Makhtesh Ramon. Bull. Geol. Surv. Isr, pp. 1 - 71.

Triebel, E., 1941. Zur Morphologie und Okologie der fossilen Ostracoden Senckenbergiana,23, pp. 294 - 400.

Urlichs, M., 1972. Ostracoden aus den Kossener Schichten und ihre Abhangigkeit von der Okologie. Mitt. Ges. Geol. Bergbaustud. Wien, 21: pp. 661 - 710.

\section{PLATE 1}

\section{Fabanella A}

1- Carapace: Left Lateral View, Sample No.B5. Hungarella moorei (Jones)-Anderson, 1964

2- Carapace: Left Lateral View, Sample No.B4.

3- Carapace: Left Lateral View, Sample No.B4. Ogmoconcha cf. blakei (Sohn, 1968)

4- Carapace: Left Lateral View, Sample No.B4.

5- Carapace: Dorsal View, Sample No.B4. Ogmoconcha bristolensis (Anderson, 1964)

6- Carapace: Left Lateral View, Sample No.B4.

7- Carapace: Dorsal View, Sample No.B4. Cytherella acuta Urlichs, 1972

8- Carapace: Left Lateral View, Sample No.B4.

9- Carapace: Right Lateral View, Sample No.B4. 


\section{Plate 1}

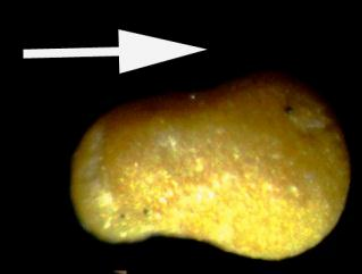

1
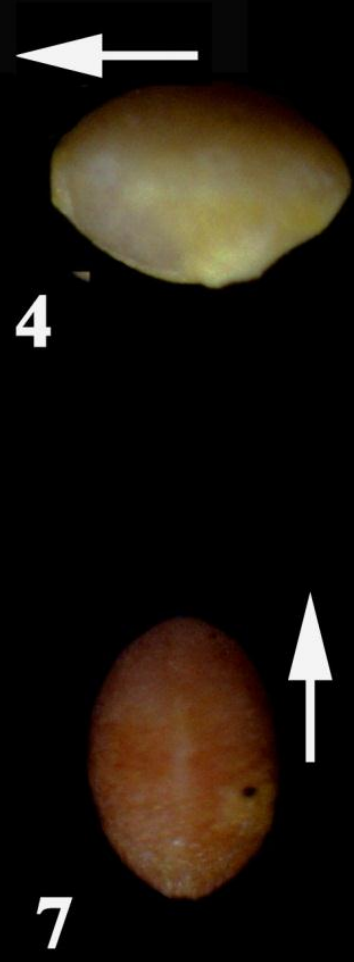

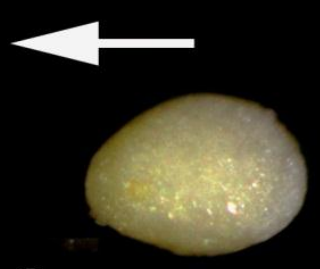

2
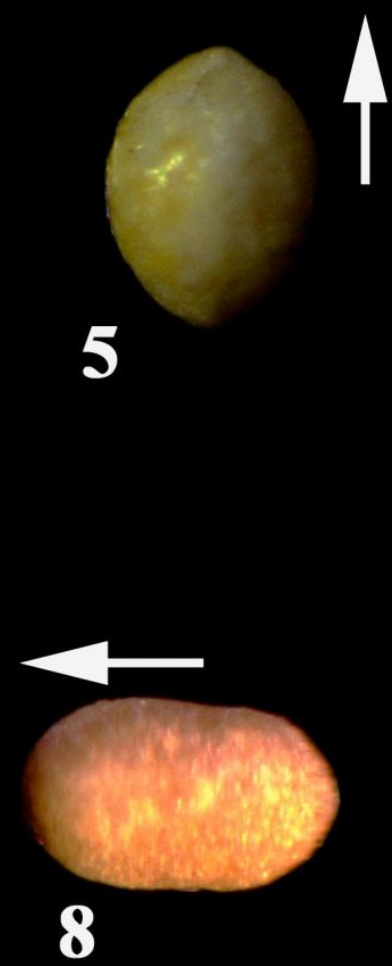
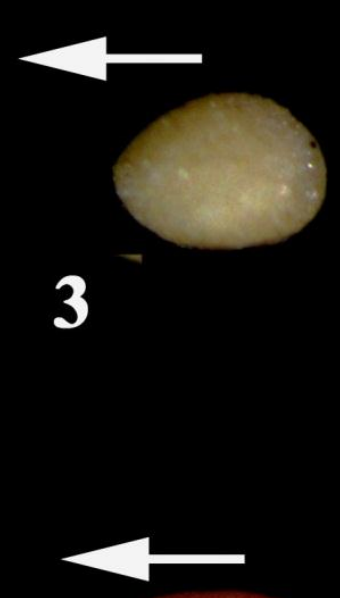

6

bar scale: $1 \mathrm{~cm}=200 \mathrm{um}$ 